\title{
Recognising Victimhood: Lessons from the International Criminal Court and Mass Claim Programmes for the Compensation Procedure Parallel to the Trial of International Crimes in the Netherlands
}

\author{
Pauline Janssen ${ }^{1} \cdot$ Renée Kool $^{1}$
}

Published online: 4 August 2017

(C) The Author(s) 2017. This article is an open access publication

\begin{abstract}
In the Netherlands, the Dutch criminal court in The Hague (hereinafter: 'Netherlands International Crimes Court' or 'NIC court') is assigned to try international crimes, and to provide compensation to victims of such crimes. Whereas it has specific criminal laws at its disposal to try international crimes, it applies 'regular' Dutch civil law to assess claims for compensation. Yet compensation for international crimes entails challenges that are quite different from domestic crimes: international crimes are normally committed against a large number of victims, and frequently result in bodily harm. This article argues that the NIC court will most likely rule a large number of claims for compensation inadmissible, as a consequence of which victims cannot benefit from the advantages inherent in the award of compensation within the criminal process. It then explores the adjudicative and reparatory standards that the International Criminal Court and mass claim programmes have applied to simplify both the adjudication of a large number of claims, and the calculation of a large number of instances of bodily damage. It is submitted that adoption by the NIC court of international reparatory standards could facilitate the assessment of a large number of civil claims within the criminal process, without prejudice to the legitimate interests of the defendant for an adequate procedure. However, these standards require the NIC court to strike a new balance between tailor-made compensation and symbolic compensation, and thereby between corrective justice and restorative justice.
\end{abstract}

This article is based on the Master's thesis of P. Janssen, written under the joint supervision of R.S.B. Kool and B. McGonigle Leyh. This thesis is unpublished, but available on request.

Pauline Janssen

Paulinecjanssen@gmail.com

Renée Kool

R.S.B.Kool@uu.nl

1 University Utrecht, Utrecht, The Netherlands 
Keywords International crimes · Compensation · International Criminal

Court · Mass claim programmes · National courts · Restorative justice

\section{Introduction}

During the Iran-Iraq war, Saddam Hussein used mustard gas to attack Iran and the Kurdish minority population in Iraq, which resulted in a total number of approximately 120,000 victims. ${ }^{1}$ Whereas this conflict appears unrelated to Dutch jurisdiction, the contrary is true. ${ }^{2}$ Where international crimes are committed by or against a Dutch person, or where the suspect is present in the Netherlands, the Dutch criminal court in The Hague has jurisdiction to try these crimes (hereinafter: 'Netherlands International Crimes Court' or 'NIC court'). ${ }^{3}$ During the Iran-Iraq war, a Dutch businessman delivered huge quantities of chemicals that were needed to produce the mustard gas used. ${ }^{4}$ The NIC court tried the Dutch businessman for complicity in war crimes in Iraq and Iran. Victims of the gas attacks lodged compensation claims parallel to the criminal procedure. ${ }^{5}$

Whereas the NIC court has specific criminal laws at its disposal to try international crimes, ${ }^{6}$ it applies 'regular' Dutch civil law to assess compensation claims lodged parallel to the criminal trial, ${ }^{7}$ also referred to as the 'adhesion procedure'. ${ }^{8}$ Yet the

\footnotetext{
${ }^{1}$ Zegveld (2009), pp. 369, 372; Foroutan (2003).

2 Other cases include: the trial of a Dutch entrepreneur for the illegal delivery of weapons to Liberia in 2002-2003 (District Court of The Hague 7 June 2006, ECLI:NL:RBSGR:2006:AX7098; Court of Appeal of The Hague 10 March 2008, ECLI:NL:GHSGR:2008:BC6068; Supreme Court 20 April 2010, ECLI:NL:HR:2010:BK8132); the trial of five suspects for membership of a criminal organisation and the financial support of the Sri Lankan Tamil Tigers (District Court of The Hague 21 October 2011, ECLI:NL:RBSGR:2011:BT8829 and ECLI:NL:RBSGR: 2011:BU2066; Court of Appeal of The Hague 30 April 2015, ECLI:NL:GHDHA:2015:1082); a trial for war crimes committed during the genocide in Rwanda in 1994 (District Court of The Hague 23 March 2009, ECLI:NL:RBSGR:2009:BI2444; Court of Appeal of The Hague 7 July 2011, ECLI:NL:GHSGR:2011:BR0686; Supreme Court 26 November 2013, ECLI:NL:HR:2013:1420).
}

${ }^{3}$ Criminal Code, Art. 2-7; Criminal Code of Procedure, Art. 2.

${ }^{4}$ Zegveld (2009), pp. 369-370.

${ }^{5}$ District Court of The Hague 23 December 2005, ECLI:NL:RBSGR:2005:AV6353.

${ }^{6}$ For instance, the legislator introduced a supplementary mode of liability derived from international criminal law: that of 'superior responsibility'. Other examples include new legal defences and immunities. See International Crimes Act 19 (June 2003), Arts. 9, 11, 16.

${ }^{7}$ International Crimes Act (19 June 2003), Art. 21a.

${ }^{8}$ In the Netherlands, 'a victim has the right to present a claim for compensation caused by an offence during the criminal trial. The claim itself is a civil claim for compensation and is governed by the rules of civil law. However, it can be presented in criminal court by means of adhesion procedure. This means that as a civil claimant, the victim joins the criminal proceedings. He is then referred to as an 'injured party'. A victim has to meet certain conditions in order to be allowed to act as a civil claimant: he should have 'suffered direct injury or loss as a result of a punishable act'. A victim may join the proceedings either by filling out an adhesion form, or by presenting the civil claim during trial. See further Brienen and Hoegen (2000), pp. 668-671. In this context questions of private international law may arise. Briefly we mention that it is acknowledged that Art. 4(1) of the Rome II Regulation 864/2007 [2007] OJ L 199/40 (coming into force on 11 January 2009), which applies to events giving rise to damage occurring from 11 January 2009 onwards, provides that the law of the country in which the damage occurs shall govern the 
compensation of international crimes entails challenges that are quite different from 'ordinary' domestic crimes. As illustrated by the example above, international crimes are of an extraordinary nature and size and are normally committed against a multitude of victims. ${ }^{9}$ Considering this fact, the NIC court may face a large amount of civil claims, even though this number has remained limited in the past. ${ }^{10}$ Furthermore, international crimes frequently result in bodily and psychological harm. ${ }^{11}$ In particular, the assessment of claims based on bodily harm is considered to be a stumbling block, because it raises difficult questions of causality and damages calculation. ${ }^{12}$

Research suggests that Dutch criminal courts will most likely rule that a large number of civil claims related to complex bodily harm amounts to a 'disproportionate burden of the criminal process', as laid down in Article 361(3) Criminal Code of Procedure (hereinafter: 'CCP'), and will therefore rule the claims inadmissible. ${ }^{13}$ Of course, the word 'disproportionate' implies interdependence between the civil claims and criminal cases. ${ }^{14}$ As international crimes are more complex to try than ordinary crimes, the NIC court may spend a proportional increase in amount of time on civil claims. However, since the definition of international crimes 'consistently points to a large number of victims', ${ }^{15}$ the number of civil claims may well exceed the proportionality threshold, in particular when the NIC court does not have tools at its disposal to deal with a large number ${ }^{16}$ of claims more easily. In such circumstances, victims of international crimes would not have the possibility of benefiting from the advantages of the adhesion procedure.

The International Criminal Court (hereinafter: 'ICC') and mass claim programmes (hereinafter: 'MCPs') may provide relevant adjudicative and reparatory

\section{Footnote 8 continued}

existence, the nature and the assessment of damage or remedy claimed. The Rome II Regulation is applicable in all Member States of the EU (except Denmark). In the Netherlands, following Art. 10:159 Civil Code, the Rome II Regulation shall apply to the obligations falling outside the material scope of the Rome II Regulation, e.g. non-contractual obligations arising out of violations of rights relating to personality. It may be argued that, if the nature of the remedy or the amount or assessment of damages as determined under the lex loci damni are in conflict with the rules of the lex fori, the problem may be solved in the context of and in accordance with the requirements of Art. 16 (mandatory provisions) or Art. 26 (public policy of the forum state) Rome II Regulation. See also Calliess (2011).

9 Groenhuijsen and Pemberton (2011), pp. 12, 22.

${ }^{10}$ The NIC court feared that a large number of victims would lodge a civil claim parallel to the trial of the Dutch businessman for complicity in war crimes in Iraq and Iran. One of the first questions the court asked was: 'there will not be 5000 victims claiming compensation, will there?' Upon advice from their lawyer, the victims from Iran and Iraq decided that only fifteen of them would file a civil complaint. Zegveld (2009), p. 373; Zegveld (2012), p. 1939. As this article shows, this is a sensible strategy in light of the limitations of the adhesion procedure.

11 Danieli (2011), pp. 240-242; Ruvebana (2011), pp. 107-115.

12 See e.g. Lindenbergh (2014), p. 2697; Ruitenbeek-Bart and Schijns (2014), p. 42; Schijns (2015), p. 33.

13 See Sect. 4.

14 Zegveld (2012), p. 1939.

15 Groenhuijsen and Pemberton (2011), p. 12.

16 The concept of a 'large number' of claims remains undefined. At the international level, there appears to be no critical threshold number marking the transition from 'claims' to 'mass claims'. It is therefore suggested that it should be left to the NIC court to decide when it uses the standards recommended in this article. See also Das (2006), p. 7. 
standards to simplify both the adjudication of a large number of civil claims, and the calculation of a large number of instances of bodily damage. So far, reparations ${ }^{17}$ have been ordered in the Lubanga case ${ }^{18}$ and in the Katanga case. ${ }^{19}$ In the Bemba case, the Chamber has issued its order requesting submissions relevant to reparations. ${ }^{20}$ Similarly, MCPs, which are established to deal with mass injury as a result of violations of state responsibility, ${ }^{21}$ have assessed thousands of claims. ${ }^{22}$ This article pays particular attention to the United Nations Compensation Commission (hereinafter: 'UNCC'), since its standards have served as a model for subsequent MCPs. ${ }^{23}$ Its practice is supported by illustrations of other MCPs that were established since the 1980s. ${ }^{24}$

As this article will demonstrate, the adoption of some international standards by the NIC court could, indeed, facilitate the wishes of victims to have their compensation claims assessed within the criminal process. These standards also acknowledge the other interests that play a role in the adhesion procedure, that is, the legitimate interests of the defendant for an adequate procedure, and the general interest of 'the criminal process' to an efficient and orderly assessment of civil claims. ${ }^{25}$ However, the NIC court cannot apply these standards without costs. Indeed, such standards require the NIC court to strike a new balance between tailor-made compensation and symbolic compensation, and thereby between corrective justice and restorative justice.

This article first provides a theoretical framework of international crimes (Sect. 2) and of the Dutch adhesion procedure (Sect. 3). Next, it discusses how civil

17 International law distinguishes five forms of reparation, namely: restitution, compensation, rehabilitation, satisfaction and guarantees of non-repetition. In contrast, Dutch law uses the concept of 'compensation' only. Non-monetary awards are referred to as 'compensation in a form other than payment of a sum of money'. See Civil Code, Art. 6:103.

18 Prosecutor v. Lubanga, ICC-01/04-01/06, Appeals Chamber, Judgment on the appeals against the 'Decision establishing the principles and procedures to be applied to reparations' of 7 August 2012 with amended order for reparations (Annex A) and public annexes 1 and 2, 3 March 2015 (hereinafter: "AC Reparations Judgment' and 'AC Reparations Order'). This judgment contains the principles and procedures of reparation, together with an amended order for reparations. The Appeals Chamber also instructed the Trust Fund, an independent institution through which the court can make reparation awards, to implement these principles in a draft implementation plan. At the time of writing, the Trust Fund is working on this draft implementation plan under the supervision of the Trial Chamber. The reparations judgment follows the conviction of Mr Lubanga of the crimes of conscripting and enlisting children under the age of fifteen and using them to actively participate in hostilities.

19 Prosecutor v. Katanga, ICC-01/04-01/07, Trial Chamber II, Ordonnance de réparation en vertu de l'article 75 du Statut, 24 March 2017. Mr Katanga was found guilty of crimes against humanity and war crimes committed during the attack on Bogoro of 24 February 2003.

${ }^{20}$ Prosecutor v. Bemba, ICC-01/05-01/08, Trial Chamber III, Order requesting submissions relevant to reparations, 22 July 2016. Mr Bemba was found guilty of war crimes and crimes against humanity, committed in the Central African Republic from on or about 26 October 2002 to 15 March 2003.

21 Caron (2014), p. 279.

22 Niebergall (2009), p. 147; Kristjánsdóttir (2009), pp. 176-177.

23 Holtzmann and Kristjánsdóttir (2007), pp. 211, 248.

24 These were selected on the basis of available resources, and include the Iran-United States Claims Tribunal, the Claims Resolution for Dormant Accounts (also referred to as 'CRT-I') and its successor (also referred to as 'CRT-II'), the German Forced Labour Compensation Programme, and the EritreaEthiopia Claims Commission.

25 Lindenbergh (2014), p. 2696. 
claims related to international crimes challenge the adhesion procedure (Sect. 4). Subsequently, it examines what adjudicative and reparatory standards the ICC and MCPs have applied to deal with civil claims related to international crimes, whether these standards safeguard all interests that play a role in the adhesion procedure, and whether Dutch law provides a statutory basis for the adoption of these standards (Sect. 5). It then considers the implications of the usage of those standards (Sect. 6). Finally, the article is summarised in the conclusion (Sect. 7).

\section{International Crimes}

The term 'international crimes' refers to crimes that originated in instruments of international law. ${ }^{26}$ The most well-known international crimes are genocide, war crimes, and crimes against humanity. Genocide comprises acts such as murder or measures to prevent births when committed with the intent to destroy, in whole or in part, a national, ethnical, racial or religious group, as such. War crimes are serious violations of the laws and customs applicable in armed conflict, and may be committed as part of a plan or policy or as part of a large-scale commission of such crimes. Crimes against humanity are acts such as murder, deportation and rape, when committed with knowledge of, and as part of a widespread or systematic attack directed against any civilian population. ${ }^{27}$

The NIC court is assigned to try five types of international crime: genocide, crimes against humanity, war crimes, torture and forced disappearances. ${ }^{28}$ The court has jurisdiction over these crimes when an international crime is committed within the territory of the Netherlands, if the crime is committed by or against a Dutch person outside the Netherlands, or if the crime is committed outside the Netherlands but the suspect is present in the Netherlands. ${ }^{29}$

International crimes appear to have at least two features in common which distinguish them from domestic crimes. First, international crimes are almost by definition targeted against large numbers of victims. ${ }^{30}$ In the case of genocide it is a 'group' which is intended to be destroyed; war crimes are committed in 'the context of and associated with' an armed conflict; and crimes against humanity are committed when there is a 'widespread or systematic attack' against a 'civilian

\footnotetext{
${ }^{26}$ Groenhuijsen and Pemberton (2011), p. 11.

27 Groenhuijsen and Pemberton (2011), pp. 11-12, referring to the definitions of these crimes in the Rome Statute.

28 International Crimes Act (19 June 2003), Arts. 3-8a. Recently, the bill proposing to criminalise the crime of aggression was adopted. See Staatsblad 2016, No. 281.

29 Criminal Code, Arts. 2-7; Military Crime Act (27 April 1903), Arts. 4-5; International Crimes Act (19 June 2003), Art. 2.

30 This may be illustrated by the fact that more than 12,000 individuals have applied to participate as victims before the ICC, and more than 9000 individuals have applied for reparations, even though so far only nine defendants have been at trial. Contreras-Garduño and Fraser (2014), p. 187; Groenhuijsen and Pemberton (2011), pp. 12, 22; War Crimes Research Office (2013), p. 1.
} 
population' ${ }^{31}$ Second, international crimes usually result in bodily and psychological harm. ${ }^{32}$ Bodily harm may consist, for instance, of disabilities as a result of beatings and shootings, and of incurable diseases such as HIV as a result of rape and sexual torture. ${ }^{33}$ Victims may also 'suffer shock and helplessness, and experience anger and grief'. ${ }^{34}$ Some victims develop more serious psychological harm such as acute stress disorder and post-traumatic stress disorder. ${ }^{35}$

\section{The Adhesion Procedure}

Victims of international crimes may file claims for compensation caused by the particular crime parallel to the criminal trial. ${ }^{36}$ The 'regular' rules on compensation apply to their claims. ${ }^{37}$ These rules make it clear that the compensation claim itself is a civil claim for compensation and is governed by rules of tort law, allowing the NIC court to rule as if it were a civil court. ${ }^{38}$ The (primary) aim of the Dutch law of tort and the law of damages is to place a victim in the same position, as he or she would have been, had no injury occurred. ${ }^{39}$ In other words, the law of tort is founded on corrective justice, that is, on the idea that wrongs must be rectified by restoring the status quo ante. ${ }^{40}$ This restoration may be achieved through factual or legal actions, ${ }^{41}$ or through the award of compensation. ${ }^{42}$

Victims may decide to lodge a civil claim in the criminal procedure, and not sue the defendant in a civil procedure, because a criminal court may impose a compensation order (in Dutch: schadevergoedingsmaatregel). ${ }^{43}$ The main

\footnotetext{
31 Groenhuijsen and Pemberton (2011), pp. 12, 22. Admittedly, in theory certain international crimes may be committed through a single act against a single victim. However, practice shows that defendants are often charged for international crimes that injured multiple victims. For instance, the ICC and the Dutch legislator added a 'contextual element' to the actus reus of genocide, requiring that the conduct took place in the context of 'a manifest pattern of similar conduct'. Cryer et al. (2010), pp. 206-208, 288; Jofriet (2009), p. 93.

32 Danieli (2011), pp. 240-242; Ruvebana (2011), pp. 107-115. Of course, international crimes may result in the loss of property rights too, such as the destruction of buildings. See also Roht-Arriaza (2004), p. 122 .

33 Ruvebana (2011), pp. 107-115.

34 Danieli (2011), p. 240; Ka Hon Chu, De Brouwer and Römkens (2011), p. 537.

35 Danieli (2011), p. 240; Ka Hon Chu, De Brouwer and Römkens (2011), p. 537.

36 International Crimes Act (19 June 2003), Art. 21a.

37 The rules of compensation are laid down in Art. 51f CCP. Arts. 332-335 CCP contain additional procedural rules. Furthermore, Art. 51h CCP instructs the judiciary to further restorative justice.

38 Parliamentary Paper I 1992/93, 21345, 36, pp. 1-2. See Giesen, Kristen and Kool (2015), p. 346.

39 Lindenbergh (2008), p. 8.

40 Lindenbergh (2008), pp. 10-11; Shelton (2015), p. 19.

41 For example, the reparation of a damaged object or the handing over of property. Hartkamp and Sieburgh (2013), para. 22.

42 Lindenbergh (2008), pp. 10-11.

43 In practice, criminal courts impose such a compensation order only when a victim has lodged a civil claim. However, a criminal court may also impose a compensation order when the victim has not lodged a civil claim, but it is clear that the victim wishes to receive compensation.
} 
advantage of the compensation order compared with the civil claim for compensation is 'the enforcement of the victim's claim by the state, which also means that all costs connected with enforcement are at the expense of the state' ${ }^{44}$ Furthermore, a criminal court may append other executorial measures to the compensation order, such as the guarantee of an advanced payment by the state, and confiscation orders. ${ }^{45}$ In contrast, a Dutch civil court has no such measures at its disposal. Once a civil court has awarded compensation to the claimant, the claimant is individually responsible for recovering the award from the accused.

In addition to the above, the adhesion procedure may offer more advantages to victims. Victims may prefer to file a claim parallel to the criminal procedure, because it provides a relatively quick way to receive compensation. This is especially true for victims of international crimes. For example, victims of the gas attacks in the Iran-Iraq war decided to initiate civil proceedings after their claims were ruled inadmissible in the criminal proceedings against the Dutch businessman who delivered chemicals to the regime of Saddam Hussein. ${ }^{46}$ The Court of Appeal awarded compensation nearly ten years after the Dutch businessman was first convicted. ${ }^{47}$ Furthermore, the assessment of claims in a criminal process may enhance feelings of acknowledgment and satisfaction, ${ }^{48}$ even though the adhesion procedure has a civil law character and merely seeks to restore the victim in his or her original position. ${ }^{49}$ Of note, the civil limb of Article 6 European Convention on Human Rights ('ECHR') also applies to civil claims lodged parallel to a criminal trial. ${ }^{50}$ This implies that a victim is "entitled to a "fair hearing" and to the other procedural rights of Article 6 ECHR'. 51

The wishes of victims stand in sharp contrast to the legitimate interests of the defendant. ${ }^{52}$ Indeed, where a civil claim is lodged parallel to the criminal trial, the defendant gains a double role: that of suspect and that of sued party. ${ }^{53}$ Therefore, the

\footnotetext{
44 Brienen and Hoegen (2000), p. 690.

45 Criminal Code, Art. 36f(1)(7); CCP, Arts. 94a(3), 572; Advanced Payment Compensation Order Implementation Decree (24 July 2010), Arts. 1, 2.

46 Court of Appeal of The Hague 9 May 2007, ECLI:NL:GHSGR:2007:BA4676; Supreme Court 30 June 2009, ECLI:NL:HR:2009:BG4822.

47 District Court of The Hague 23 December 2005, ECLI:NL:RBSGR:2005:AX6406; Court of Appeal of The Hague 7 April 2015, ECLI:NL:GHDHA:2015:725.

48 However, victims have also considered their 'side role' as an injured party in the criminal process as a negative experience. Van Dongen, Hebly and Lindenbergh (2014), pp. 4, 6.

49 Van Dongen, Hebly and Lindenbergh (2014), p. 4.

50 E.g. ECtHR 12 February 2014, $47287 / 99$ (Perez v. France). Art. 6(1) ECHR reads: 'In the determination of the civil rights and obligations or of any criminal charge against him, everyone is entitled to a fair and public hearing within a reasonable time by and independent and impartial tribunal established by law'.

51 The Strasbourg Court has considered that a fair civil proceeding requires that a national court examines each party's allegations properly and thoroughly: 'The effect of Article 6 para. 1 [...] is, inter alia, to place the "tribunal" under a duty to conduct a proper examination of the submissions, arguments and evidence adduced by the parties, without prejudice to its assessment of whether they are relevant to its decision'. ECtHR 12 February 2014, $47287 / 99$ (Perez v. France), para. 80.

52 Lindenbergh (2014), p. 2696.

53 Candido (2012), p. 940.
} 
Supreme Court (Hoge Raad) has ruled that Article 6 ECHR entails that a criminal judge must rule a civil claim inadmissible when it is not convinced that the defendant has been able to dispute all facts related to the civil claim, and where necessary, has been able to support this position with evidence. ${ }^{54}$ In the words of a local court: 'The fact that the adhesion procedure provides an injured party the advantage of a quick judgment, does not imply that such a quick judgment should be provided at the costs of the accused, and his or her possibilities to dispute the claims in a civil procedure' 55

The admissibility criterion set out in Article 361(3) CCP safeguards both the interest of victims and that of the defendant. ${ }^{56}$ According to this Article, a criminal court may declare a claim, or part of a claim, inadmissible 'if the handling of the claim will cause a disproportionate burden to the criminal process, hindering the criminal trial'. 57 This 'disproportionate burden' criterion leaves ample room to assess a relatively clear-cut claim in the criminal process. At the same time, it demands a criminal court to declare a claim inadmissible if the interests of the defendant cannot be safeguarded, which may be the case, for instance, if the defendant wishes to remain silent during the criminal trial, and accordingly will not dispute the facts related to the civil claim. ${ }^{58}$ In addition, it may be argued that the 'disproportionate burden' requirement also secures 'the general interest of the criminal process' to an efficient and orderly assessment of claims. ${ }^{59}$ Indeed, the criterion authorises a criminal court to dismiss a claim if the assessment of a claim would take too much of its attention, thereby distracting the court from its main task: the examination of the criminal culpability of the defendant. To put it differently: the admissibility requirement preserves the accessory character of the adhesion procedure. ${ }^{60}$

\footnotetext{
54 Supreme Court 15 September 2006, ECLI:NL:HR:2006:AV2654 [translation PJ and RK]. Of note, the injured party must also have these possibilities.

55 District Court of Limburg 30 July 2015, ECLI:NL:RBLIM:2015:6521 [translation PJ and RK].

56 The debates related to the modernisation of the Dutch Criminal Code of Procedure illustrate the current political willingness to serve the victim's interest. The Dutch government proposes an independent right for an injured party to appeal an unfounded ruling of his or her civil claim, which would have to be assessed by a criminal law judge. Parliamentary Paper II 2015/2016, 29279, 278, para. 2.5.3. See further Keulen (2015); Lindenbergh (2014), p. 2696.

57 Art. $361 \mathrm{CCP}$ sets out three conditions that relate to the admissibility of a civil claim in the criminal process. First, a claimant must qualify as an injured party. The second condition entails that the civil claim for compensation is only admissible if the accused is found guilty and a penal sanction or measure is imposed. The third criterion is the disproportionate burden requirement.

58 Candido et al. (2013), p. 89.

59 Lindenbergh (2014), p. 2696.

${ }^{60}$ However, since the position of victims in Dutch criminal proceedings is increasingly reinforced, the accessory nature of the adhesion procedure is subject to debate. See Keulen (2015).
} 


\section{The Challenges International Crimes Pose to the Adhesion Procedure}

As explained above, international crimes are frequently committed against a large number of victims, who often experience bodily and psychological harm. Victims may lodge civil claims parallel to the trial of these international crimes before the NIC court. ${ }^{61}$ This raises the question whether the NIC court can manage to assess a large number of civil claims related to bodily and psychological harm.

The admissibility criterion of Article 361(3) CCP does not provide an answer. As discussed, this criterion entails a disproportionate burden requirement. The government exemplified that the following situations may not lead to inadmissibility: (a) the fact that the civil claim is challenged; (b) the fact that the civil claim is not immediately corroborated with sufficient evidence; (c) the fact that a sole witness or expert must be examined; (d) the fact that the amount of compensation claimed is above average. ${ }^{62}$ In other words, the government has not commented on the consequences of a large amount of civil claims related to bodily and psychological harm for the adhesion procedure.

From Dutch legal practice it is not clear whether a large number of civil claims necessarily leads to a disproportionate burden of the criminal process. ${ }^{63}$ However, in the Roberts $M$. case the Supreme Court did, in the specific circumstances of the case, comment on the admissibility of many civil claims related to complex injury. Roberts M., who worked at several day-care centres, was convicted for the abuse of 67 very young children, and the possession, production and distribution of child pornography. The parents of the children lodged fifty-six civil claims. The claims raised difficult issues concerning the nature of the damage, the subjects of the damage, and the scope of the damage. ${ }^{64}$ The Supreme Court refused to send back the case to the Court of Appeal, stating that in all reasonableness, it could not be said that this does not amount to a disproportionate burden to the criminal process'. ${ }^{65}$ To put it differently: the large number of claims, in combination with the complexity of the claims, amounted to a disproportionate burden of the criminal process. $^{66}$

When, then, do Dutch criminal courts generally consider civil claims as complex? In practice, the nature of particular harm may impact on the admissibility

\footnotetext{
61 International Crimes Act (19 June 2003), Art. 21a.

62 Parliamentary Paper II 2007/08, 30143, 16.

63 Lower courts have ruled differently when faced with a large amount of claims related to property damage. For instance, the Court of Appeal of Den Bosch ruled that a large amount of civil claims necessarily leads to an admissibility ruling (Supreme Court 18 April 2006, ECLI:NL:HR:2006:AU8117), whereas the Court of Appeal of Arnhem granted 482 claims that were based on specific amounts that claimant had invested in a company (Court of Appeal of Arnhem, 19 July 2001, ECLI:NL:GHARN: 2001:AB2802); Kool et al. (2016), para. 3.8.

64 Kool et al. (2016), p. 53; Schijns (2015), p. 38.

65 Supreme Court 16 September 2014, ECLI:NL:HR:2014:2668 (Roberts M.) [translation JP and RK].

66 See also Schijns (2015), p. 38.
} 
decision of criminal courts. ${ }^{67}$ A claim related to property damage is often assessed within the criminal process. ${ }^{68}$ Similarly, criminal courts have considered the award of compensation for psychological harm as less problematic, simply supposing certain crimes always cause psychological damage. ${ }^{69}$ In contrast, criminal courts consider a civil claim based on bodily injury as complex, and have frequently ruled such a claim inadmissible. ${ }^{70}$ Bodily damage may raise difficult questions concerning causality. ${ }^{71}$ Moreover, the calculation of the scope of bodily damage also appears a stumbling block. ${ }^{72}$ In case of property damage, the question what constitutes the loss does not leave much room for discussion. ${ }^{73}$ The opposite is true for bodily damage, which may affect residual working capacity, the need for domestic help, questions of re-integration, and so on. ${ }^{74}$ For these questions, experts may need to be consulted. ${ }^{75}$

The above suggests that criminal courts most likely will dismiss a large number of civil claims related to bodily harm. ${ }^{76}$ Indeed, criminal courts would have to assess complex causality questions for each claim separately, and would also have to calculate complicated bodily damage for each individual claim. Moreover, the court must make many more decisions, ${ }^{77}$ such as whether claims are filed correctly. ${ }^{78}$ Of course, it may be argued that the NIC court does not need to rule such claims inadmissible. Indeed, the word 'disproportionate' implies interdependence between the civil claim and the criminal case. As the criminal case gets bigger and more complex, as is the case with international crimes, a proportionate increase in amount of time spent on assessing civil claims should not necessarily result in inadmissibility. ${ }^{79}$ However, this is not a long-term solution to provide victims of international crimes with the adequate possibility of benefiting from the

\footnotetext{
${ }^{67}$ E.g. Candido and Lindenbergh (2014); Lindenbergh (2014); Ruitenbeek-Bart and Schijns (2014); Schijns (2015). Other factors that may affect the admissibility decision are the number of claims, the amount of compensation claimed, and whether the defendant disputes the claims. Kool et al. (2016), p. 149.

68 Schijns (2015), p. 35, after an examination of about fifty cases.

69 This differs from the approach of civil courts. See further Candido and Lindenbergh (2014); Kool et al. (2016), Chapter 6

70 Lindenbergh (2014), p. 2699; Schijns (2015), p. 35, after an examination of about fifty cases.

71 For instance: What bodily damage is the direct result of international crimes, and how do these damages obstruct a victim for being able to work? Lindenbergh (2014), p. 2697; Ruitenbeek-Bart and Schijns (2014), p. 42; Schijns (2015), p. 33.

72 Lindenbergh (2014), p. 2697; Schijns (2015), p. 33.

73 Schijns (2015), p. 35. For challenges concerning the evaluation of property loss, see further Hartkamp and Sieburgh (2013), para. 32.

74 Ruitenbeek-Bart and Schijns (2014), p. 42.

75 Lindenbergh (2014), p. 2697.

76 See also Schijns (2015), p. 40.

77 In his commentary to Supreme Court 20 April 2004, ECLI:NL:HR: 2004:AN9379, J.M. Reijntjes wrote: 'when 500 victims join the criminal case as a civil party, a judge must make 2000 extra decisions'. See NJ 2004, 681.

78 See further Claassens (2007), p. 98.

79 Zegveld (2012), p. 1939.
} 
advantages of the adhesion procedure. Considering that the definitions of international crimes 'consistently point to a large number of victims', ${ }^{80}$ the number of civil claims lodged may well exceed the proportionality threshold. A long-term solution would be to have a system in place that enables the NIC court to deal with a large number of victims more easily. Lessons may be drawn from the ICC and MCPs to simplify both the adjudication of many complex claims and the calculation of a large number of instances of bodily damage.

\section{Solutions Offered at the International Level}

As the NIC court will most likely rule a large number of compensation claims related to international claims inadmissible, this section explores the adjudicative and reparatory standards that the ICC and MCPs have applied. It also discusses whether these standards are appropriate for the NIC court to use (Sect. 5.1). It examines whether these standards safeguard all interests that play a role in the adhesion procedure (Sect. 5.2), and whether Dutch law provides a statutory basis for these standards (Sect. 5.3).

\subsection{Standards Used by the ICC, MCPs and the NIC Court}

The ICC and MCPs do not provide relevant solutions to expedite the adjudication of many civil claims. Indeed, the ICC has used similar adjudicatory standards as the NIC court. It rejected the 'de-judicialized' standards of MCPs, such as a lowered standard of proof, ${ }^{81}$ the grouping of claims, ${ }^{82}$ and the delegation of judicial tasks to non-judicial organs. ${ }^{83}$ Instead, the ICC affirmed the judicial nature of reparations. ${ }^{84}$ In the Lubanga case, the Appeals Chamber set the standard of proof at 'a balance of

\footnotetext{
${ }^{80}$ Groenhuijsen and Pemberton (2011), p. 12.

81 Some MCPs, among which the UNCC, the Claims Resolution for Dormant Accounts (also referred to as 'CRT-I') and its successor (also referred to as 'CRT-II'), have applied a lower standard of proof, usually referred to as the standard of plausibility, which merely requires the claimant to submit all evidence it could reasonably submit. See UNCC Provisional Rules for Claims Procedure (1992), Art. 35; Rules of Procedure for the Claims Resolution Process of the Claims Resolution for Dormant Accounts (23 July 1997), Art. 22; Rules Governing the Claims Resolution Process of the Claims Resolution for Dormant Accounts (2001), Art. 17(1). See further Holtzmann and Kristjánsdóttir (2007), pp. 211-222; Niebergall (2009), p. 159.

82 The UNCC and the Eritrea-Ethiopia Claims Commission were both expressly authorised to rely on sampling. This method entails the grouping of claims that present similar legal and factual issues. The decision-making body is then allowed to analyse a few individual claims within a group of claims, and extrapolate the results to other claims within the group. Holtzmann and Kristjánsdóttir (2007), p. 244.

83 The UNCC delegated judicial review to its secretariat, a non-judicial organ. The secretariat matched claims against 'information, which was contained in a computer database'. These claims were then considered verified, and were only crosschecked by the decision-making body. Heiskanen (2006), pp. 3334; Gibson (1997), pp. 182-183; Taylor (2009), p. 210.
}

84 Stahn (2015), p. 809. 
probabilities, ${ }^{85}$ which resembles the Dutch probability test that is used in the adhesion procedure. ${ }^{86}$ It also emphasised that the defendant must have the opportunity to submit observations on the eligibility of each claimant, ${ }^{87}$ thus implicitly rejecting the grouping of claims. Furthermore, it stressed that judicial tasks, such as the examination of causality and the identification of harm, cannot be delegated to a non-judicial organ. ${ }^{88}$ This approach must be understood in the light of the nature of the ICC. Unlike MCPs, which frequently have an administrative nature and deal with state responsibility, the ICC is engaged with individual criminal responsibility. ${ }^{89}$ Hence, it must take into account the rights of the defendant, and is less victim-orientated. ${ }^{90}$ Similarly, the NIC court must uphold judicial standards. Of note, this is not to say that the work of the non-judicial organs of the ICC should be disregarded. On the contrary, the work of these organs may serve as a model for the NIC court. Indeed, ICC Chambers delegate a large amount of administrative work to non-judicial organs. For instance, the Registry is responsible for 'the non-judicial aspects of the administration and servicing of the Court'. ${ }^{91}$ In addition, the Chambers may ask the Trust Fund for Victims ${ }^{92}$ to inquire into appropriate forms of reparations. ${ }^{93}$ The creation of a similar organ, which would, for instance, review whether all claims are filed according to procedure, ${ }^{94}$ could expedite the assessment of a vast number of claims. ${ }^{95}$

Even though the ICC and MCPs do not apply apt adjudicatory standards to simplify the adjudication of many claims, they do provide two solutions to evaluate a large number of damages more easily. First, the ICC does not provide only

\footnotetext{
85 AC Reparations Judgment, para. 83. These reparation principles are established on a case-by-case basis (AC Reparations Order, para. 5). However, in the Katanga case, parties have already suggested that the same reparation principles should apply. E.g. Prosecutor v. Katanga, ICC-01/04-01/07-3532, Trial Chamber II, Registry's Observations pursuant to Order, 15 May 2015, para. 9; Prosecutor v. Katanga, ICC-01/04-01/07, Trial Chamber II, Defence Consolidated Response to the Parties, Participants and Other Interested Persons' Observations on Reparation, 16 June 2015, para. 5.

86 The standard implies that the court must be 'more sure than unsure' and could be compared to the English 'balance of probabilities test'. Giesen (2001), p. 57.

87 Prosecutor v. Lubanga, ICC-01/04-01/06, Trial Chamber II, Order instructing the Trust Fund for Victims to supplement the draft implementation plan, 9 February 2016, para. 14 (hereinafter: 'TC Order').

88 AC Reparations Judgment, para. 1.

89 Caron (2014), p. 279; Wühler (2003), p. 392.

90 Stahn (2015), pp. 805, 807, 809.

91 Rome Statute of the International Criminal Court, A/CONF.183/9 (17 July 1998), Art. 43(1).

92 The Trust Fund is an independent institution through with the court can make reparation awards. Bitti and Ravas (2006), p. 300.

93 Rome Statute, Art. 75(2); Rules of Procedure and Evidence of the International Criminal Court, ICCASP/1/3 (9 September 2002), Art. 98(2-4); Regulations of the Trust Fund for Victims, ICC-ASP/4/Res.3 (3 December 2005), Arts. 55, 57, 69. In the Lubanga case, the Trial Chamber asked the Trust Fund to make a proposal for forms of reparations. TC Order, para. 21.

94 See e.g. Claassens (2007), p. 98.

95 Of course, the victims' lawyers also play a role in streamlining this process, for instance by providing adequate documentation to corroborate claims. See Kool et al. (2016), p. 101.
} 
monetary compensation, but also reparation in the form of satisfaction. $^{96}$ Satisfaction can take many forms, including a formal apology. ${ }^{97}$ In contrast, Dutch law primarily points to monetary compensation. ${ }^{98}$ Admittedly, the Civil Code does leave room for compensation in a form other than payment of a sum of money, namely, in natura. ${ }^{99}$ However, compensation in natura remains a form of compensation, ${ }^{100}$ which means it seeks to restore the situation that prevailed prior to the offence. ${ }^{101}$ Compensation in natura has therefore largely been confined to, for instance, the reparation of a damaged object or the handing over of property. ${ }^{102}$ So far, it appears there are only two examples of rehabilitation awards, which do not focus on the past but instead focus on the recovery of the victim in the future. ${ }^{103}$

Second, MCPs do not quantify the harm of each person individually, but use fixed amounts of monetary compensation. ${ }^{104}$ For instance, the UNCC awards fixed compensation depending on the type of injury and the size of damage. The amount of compensation for forced departure from Kuwait or Iraq was fixed at US \$2500 for individuals, whereas those who suffered serious bodily injury received a fixed amount of US $\$ 2500$ for each injury. ${ }^{105}$ Similarly, the Eritrea-Ethiopia Claims Commission $^{106}$ awarded fixed amounts depending on the type of evidence

\footnotetext{
96 Art. 75 Rome Statute does not mention 'satisfaction' as a form of reparation. However, the word 'including' indicates that the forms of reparations mentioned in Art. 75 are not exhaustive. Moreover, it was the express intention of the parties negotiating the Statute that for the purposes of interpreting the term 'reparations', the court shall take into consideration the definitions of the 1985 Victims Declaration, which now have been adopted as the Victim Principles (16 December 2005), and which does mention 'satisfaction'. Dwertmann (2010), p. 129; McCarthy (2012), pp. 169-170.

97 Other forms include the creation of monuments and the organisation of memorials. McCarthy (2012), pp. 170, 181-182. However, such reparation modalities are not suited for reparations on the national level. Where international crimes are committed outside the Netherlands, it is unclear how such awards would be implemented or enforced for victims who live abroad.
}

98 Art. 6:103 Civil Code reads: 'Damages shall be paid in money. Nevertheless, upon the demand of the person suffering the loss, the court may award compensation in a form other than payment of a sum of money. Where such judgment is not complied with within a reasonable period, the person suffering the loss shall recover the right to claim damages in money' (translation: Warendorf's Dutch Civil and Commercial Legislation). Following parliamentary history 'reparation in another form may cause new problems'.

99 Such compensation in natura may take any form, and may require factual or legal actions. Hartkamp and Sieburgh (2013), para. 22.

100 Oosterveen and Frenk (2015), para. 2.

101 Hartkamp and Sieburgh (2013), para. 21.

102 Hartkamp and Sieburgh (2013), para. 22.

103 See District Court of the Netherlands Antilles, NJ 1973, 314 (date unknown to the authors); District Court of Zwolle 23 December 1992, ECLI:NL:RBZWO:1992:AJ6195.

104 Some mass claim processes granted awards on a case-by-case basis. For instance, the Iran-United States Claims Tribunal does not use fixed awards. Holtzmann and Kristjánsdóttir (2007), p. 74.

105 Decision No. 1: Criteria for Expedited Processing of Urgent Claims, UN Doc. S/AC.26/1991/1 (2 August 1991), paras. 10-13.

106 Between 1998 and 2000, Eritrea and Ethiopia engaged in a war. In 2000, the Eritrea-Ethiopia Claims Commission was established and given 'the mandate to decide claims by both parties for specified types of loss, damage, and injury related to the conflict, and resulting from violations of international humanitarian law or other violations of international law'. See further Holtzmann and Kristjánsdóttir (2007), pp. 33-34. 
available, ${ }^{107}$ and the German Forced Labour Compensation Programme ${ }^{108}$ granted fixed awards on the basis of different categories of victim groups. ${ }^{109}$ At the ICC, the Registry in the Katanga case defended 'the possibility of standardised awards for particular types of harm as opposed to individually assessed awards'. ${ }^{110}$ It expects that 'in many cases it will be feasible to establish that harm occurred, what type of harm, and the fact that this was linked to the crimes committed. On the other hand, it may be much more difficult to obtain evidence on the basis of which damage can be quantified for each victim individually'. ${ }^{111}$ In its recent Order for Reparations, the Trial Chamber used a fixed monetary value for each type of injury to calculate the harm suffered by the victims collectively. ${ }^{112}$ Dutch practice takes the opposite point of departure. Indeed, Dutch courts normally calculate damages in a concrete way. This is so because compensation seeks to restore the injured party to his original position. ${ }^{113}$ Concrete calculations take into account the individual circumstances of each particular case in order to compensate real damage, no more and no less. ${ }^{114}$ In exceptional circumstances, courts have used abstract calculations in relation to property damage. Such an abstract calculation is based on objective standards rather than on the specific circumstances of the case. In other words, a judge considers what the scope of damage would normally be in a similar situation. ${ }^{115}$ However, bodily damage is typically calculated in an individual manner. ${ }^{116}$

\subsection{Advantages and Disadvantages of the Adoption of International Reparatory Standards by the NIC Court}

The award of a formal apology could reconcile the competing interests that play a role in the adhesion procedure. The award furthers the general interest of the

\footnotetext{
107 Decision No. 2: Claims categories, forms and procedures, EECC (24 July 2001), part B.

108 The German Forced Labour Programme 'aimed to give financial reparations to the victims of certain injustices committed by the Nazi regime during World War II'. See further Holtzmann and Kristjánsdóttir (2007), pp. 29-32.

109 Niebergall (2009), p. 164.

110 Prosecutor v. Katanga, ICC-01/04-01/07, Trial Chamber II, Registry's Observations pursuant to Order ICC-01/04-01/07-3532, 15 May 2015, para. 11. Thus, far, the ICC has only ordered collective reparations. However, in the Katanga case, victims expressed a specific desire for individual financial reparations. Prosecutor v. Katanga, ICC-01/04-01/07, Trial Chamber II, Queen's University Belfast's Human Rights Centre (HRC) and University of Ulster's Transitional Justice Institute (TJI) Submission on Reparations Issues pursuant to Art. 75 of the Statute, 14 May 2015, para. 28. Similar wishes were expressed in the Kenya cases, see Human Rights Centre (2015), p. 3.

111 Prosecutor v. Katanga, ICC-01/04-01/07, Trial Chamber II, Registry's Observations pursuant to Order ICC-01/04-01/07-3532, 15 May 2015, para. 11.

112 Prosecutor v. Katanga, ICC-01/04-01/07, Trial Chamber II, Ordonnance de réparation en vertu de l'article 75 du Statut, 24 March 2017.

113 Hartkamp and Sieburgh (2013), paras. 31-32.

114 Hartkamp and Sieburgh (2013), para. 32.

115 Hartkamp and Sieburgh (2013), para. 35.

116 Although the Supreme Court has assessed bodily damage with regard to objective measures before. E.g. Supreme Court 28 May 1999, ECLI:NL:HR:1999:ZC2912; Supreme Court 5 December 2008, ECLI:NL:HR:2008:BE9998. See further Hartkamp and Sieburgh (2013), paras. 36, 43, 150.
} 
criminal process for an efficient and orderly assessment of claims, as the NIC court would not have to assess harm, but only identify the type of harm. The award may be considered beneficial to victims, too. Critics who argue that courts should not monopolise something that belongs to victims, ${ }^{117}$ or contend that apologies are only meaningful if they are made voluntarily, ${ }^{118}$ do not explain why the NIC court should not award apologies under certain circumstances. Of course, the NIC court should always consult victims before it awards apologies. Moreover, not all awarded apologies are necessarily made involuntarily. And, even when an apology is expressed involuntarily, victims may still appreciate the award itself as meaningful, because an authoritative court recognised the wrong that was done to them. ${ }^{119}$ Indeed, due to the symbolic function of the criminal law, as the ultimate forum for the public acknowledgement of unlawful victimisation, criminal courts are in a unique position to recognise victims of their victimhood by awarding an apology. ${ }^{120}$ Furthermore, the award of this form of reparation does not violate the right of the defendant, because the award necessarily follows a conviction.

Similarly, standardised awards could reconcile the interests pertaining to the adhesion procedure. Again, fixed awards facilitate the general interest of the criminal process for an efficient and orderly assessment of claims, as the NIC court would still have to identify harm, but would not have to assess this harm. At a first glance, fixed awards may appear unfair to victims, as they do not reflect upon the different degree and light of harm they endured. ${ }^{121}$ However, set awards may be the only workable approach for victims to receive individual compensation with the advantages of, among other things, executorial criminal measures. Moreover, standardised awards may reflect injury to some extent, by using categories based on types of injury. ${ }^{122}$ In addition, the adoption of fixed awards an sich does not necessarily need to weaken the legitimate interests of the defendant. ${ }^{123}$ Where awards are fixed at a standard that is in line with civil law norms, the defendant does not pay more than he or she would otherwise have to pay. ${ }^{124}$ In fact, standardised awards might improve the interests of the defendant, as Dutch criminal courts currently award compensation with reference to a computer programme or to a list containing index linked awards, neither of which correspond to civil law standards nor were designed for judicial purposes. ${ }^{125}$ And, of course, the adoption of fixed

\footnotetext{
117 Schotsmans (2005), p. 116.

118 The Bosnian Chamber of Human Rights has refrained from ordering an apology on this ground. Hermas v. Federation, case No. CH/97/45, Decision on Admissibility and Merits, 18 February 1998.

119 This may be illustrated by the example of a mother telling her eldest child to apologise to her youngest child. This indicates to the younger child that the mother ('the authoritative law') understands that the eldest child has been unjustly harmed and the adult will not tolerate it. Smith (2014), p. 77.

${ }^{120}$ Kool (2014), p. 15; Pemberton et al. (2015), p. 366.

121 Niebergall (2009), p. 164; Kool et al. (2016), Chapter 7.

122 In legal writing, fixed awards based on types of injury have been prioritised over fixed awards based on victim groups. Niebergall (2009), p. 164.

123 Lindenbergh (2014), p. 2702.

124 Lindenbergh (2014), p. 2702.

125 Instead, they were established for use by the Prosecution and an autonomous administrative authority, Candido and Lindenbergh (2014).
} 
awards is without prejudice to the understanding that the NIC court must rule civil claims inadmissible if a defendant wishes to remain silent during his criminal trial, and will not dispute the facts related to the claims. ${ }^{126}$

\subsection{Statutory Basis in Dutch Law}

Even though Dutch law primarily points to monetary compensation, there is a statutory provision that may serve as a basis for the award of apologies. According to Article 6:103 Civil Code, the NIC court may award compensation in a form other than the payment of a sum of money, namely, in natura. ${ }^{127}$ Although compensation in natura has remained largely confined to legal and factual actions to restore the situation that prevailed prior to the offence, for instance by the reparation of a damaged object, Dutch lawyers have increasingly stressed the need for the concept of 'rehabilitation'. ${ }^{128}$ It has been argued that, rather than focusing on the past, courts should concentrate on the possibilities available to assist the claimant's recovery, and award remedies such as apologies. ${ }^{129}$

Similarly, Article 6:97 Civil Code provides a statutory basis for standardised awards, stating that 'the court shall assess the damage in a manner most appropriate to its nature'. ${ }^{130}$ Even though injury is normally calculated in a concrete way, under certain circumstances, for reasons of practicality and equality, an abstract manner of assessing damages is acceptable. ${ }^{131}$ It is submitted that such reasons of practicality are apparent when a large number of complex claims are lodged before the NIC court. A new 'list', designed by the Dutch legislator, containing categorised awards may enhance simplification of the assessment of damages. There are many examples that could serve as a guideline. ${ }^{132}$ For example, the Catholic Church uses standardised awards to compensate for sexual assault. ${ }^{133}$ Similarly, the Affection Damage Bill, which aims to introduce the possibility to claim damages for the pain and grief a relative suffers as a result of the death or injury of his next of kin, also makes use of standardised awards. ${ }^{134}$

\footnotetext{
126 Supreme Court 15 September 2006, ECLI:NL:HR:2006:AV2654.

127 The claimant must request such a type of reparation, so that he is not unwillingly forced with a another type of compensation. The court has a discretionary power as to whether or not to comply with this request. However, the court must bear in mind that, if the request is appropriate, the claimant has a right to receive compensation in natura. Hartkamp and Sieburgh (2013), para. 21.

128 E.g. Van Dijck (2015); Hartlief (2015); Loth and Stegerhoek (2016).

129 Van Dijck (2015), p. 2531; Loth and Stegerhoek (2016), p. 99.

130 Translation: Warendorf's Dutch Civil and Commercial Legislation.

131 Oosterveen and Frenk (2015), para. 2a.

132 Lindenbergh (2014), p. 2701; Kool et al. (2016), pp. 68-70, 229-233.

133 See https://www.meldpuntmisbruikrkk.nl/S/Schade/Paginas/Werkwijze.aspx.

134 Parliamentary Paper II, 2014-2015, 34257, 3 (explanatory memorandum), see https://www. rijksoverheid.nl/documenten/kamerstukken/2015/07/20/memorie-van-toelichting-vergoedingaffectieschade.
} 


\section{Implications of the Introduction of New Standards in the Adhesion Procedure}

Reparations in the form of a formal apology or in the form of standardised awards oppose the traditional aim of Dutch tort law. Indeed, Dutch tort law seeks to restore a victim to the status quo before the injury occurred. This principle implies that damage that did occur must be fully compensated. ${ }^{135}$ In contrast, the reparatory standards used by the ICC and MCPs are of a symbolic nature, in recognition of the victims suffering rather than in an attempt to compensate the individual losses and suffering of each victim. ${ }^{136}$

The approach of the ICC and MCPs corresponds with the concept of restorative justice, ${ }^{137}$ which emerged in the context of international crimes. ${ }^{138}$ The traditional aim of reparations, which is to correct injustice and replace the victim in the position he or she would have been had the violations not occurred, has seemed inadequate for international crimes. ${ }^{139}$ The consequences of international crimes are by their very nature irreparable. ${ }^{140}$ As explained in legal commentary: 'what could replace lost health and serenity, the loss of a whole extended family, a generation of friends, the destruction of a culture or an entire community? ${ }^{141}$ Moreover, the traditional approach fails to recognise that restitution to the situation before the injuries occurred is undesirable, considering that inequalities and injustices enabled international crimes to occur in the first place. ${ }^{142}$ Like corrective justice, restorative justice seeks to repair harm. ${ }^{143}$ However, it takes into consideration the larger context of widespread violations, is future-oriented ${ }^{144}$ and focuses on the restoration of dignity and the acknowledgement of the harm suffered. ${ }^{145}$ Victims of international crimes frequently have become mere objects in the eyes of

\footnotetext{
135 Hartkamp and Sieburgh (2013), para. 32. Note that the aims of tort law are subject to current debate in the Netherlands. See further Kool et al. (2016).

136 Niebergall (2009), p. 165; The Trial Chamber in the Katanga case awarded symbolic reparations of USD 250 per victim, while stressing this amount was not meant to compensate for the entirety of the harm suffered. Rather, it should be considered as 'relief' for the suffering. See Prosecutor v. Katanga, ICC-01/ 04-01/07, Trial Chamber II, Ordonnance de réparation en vertu de l'article 75 du Statut, 24 March 2017. 137 The Rome Statute is silent on the purpose of ICC reparation orders. In its Appeals Judgment, the Appeals Chamber does not focus on compensation, but seeks to recognise victimhood by, for instance, recognising harm in the Reparation Order. Dwertmann (2010), p. 37; Stahn (2015), pp. 801, 811.

138 Shelton (2015), p. 23.

139 Correa (2011), p. 188; Dwertmann (2010), p. 37; Kristjánsdóttir (2009), p. 167; Roht-Arriaza (2004), p. 122.

140 Dwertmann (2010), p. 37.

141 Roht-Arriaza (2004), p. 122.

142 Saris and Lofts (2009), p. 81.

143 Shelton (2015), p. 23.

144 For a similar plea for future-oriented compensation, see Van Boom (2007), arguing that compensation is not only a means to restore an ex-ante situation, but also a means to prevent further violations of the norm it seeks to protect.

145 Shelton (2015), pp. 23, 26. For necessary components for healing in the wake of massive trauma, see also Correa (2011), p. 191; Danieli (2011), p. 245.
} 
perpetrators. ${ }^{146}$ Restorative justice aims to reverse their exclusion from society, ${ }^{147}$ by providing both symbolic and monetary reparations. ${ }^{148}$

Taking into account the context of international crimes, a lex specialis departing from the traditional principle of Dutch tort law is justified. Reparations should carry a message of inclusion and recognition, by providing, for example, apologies. It is not uncontested whether fixed awards, because of their de-individualised nature, could carry such a message of recognition. ${ }^{149}$ However, such a message of inclusion may be better communicated to victims by awarding standardised measures, than by ruling claims inadmissible because it was too challenging for the NIC court to assess a large amount of claims separately. In fact, it might be the only practical way the NIC court can recognise victimhood and provide individual compensation.

\section{Conclusion}

It is submitted that the NIC court should use the existing Dutch statutory provisions to award apologies and fixed compensation. This would enable the NIC court to expedite the assessment of a large amount of civil claims, and reconcile the competing interests of the adhesion procedure. Victims could benefit from the advantages that the adhesion procedure provides, and claims would be assessed in an efficient and orderly manner, without necessarily affecting the position of the defendant. $^{150}$

The use of standardised awards raises new questions. For instance, it will have to be discussed whether the convicted person should be given the opportunity to dispute a set amount of compensation, and whether mitigating factors should be applied. ${ }^{151}$ The Netherlands will also have to consider if, and if so how, it will fund compensation awards if the defendant is unable to pay for all victims. ${ }^{152}$

\footnotetext{
${ }^{146}$ Victims of mass killing become simply 'objects' of perpetrators' actions through the processes of usthem thinking, moral disengagement and blaming the victims. Correa (2011), pp. 189, 191; Groenhuijsen and Pemberton (2011), p. 29.

147 This exclusion has also been referred to as 'the social death of victims'. Groenhuijsen and Pemberton (2011), p. 29.

${ }^{148}$ Letschert et al. (2011), p. 627; Shelton (2015), pp. 24, 26-27. See also Correa (2011), p. 191; Danieli (2011), p. 245.

149 See for instance Akkermans (2008), a research into the wishes of victims in the Dutch civil procedure.

150 See Lindenbergh (2014), p. 2702.

${ }^{151}$ Following the Arts. 6:100, 6:101, 6:109 Civil Code, once a court has calculated due compensation, it may change this amount for several reasons. First, a benefit which the victim has gained as a consequence of the event that caused the damage must, to the extent that this is reasonable, be quantified in determining the damage to be repaired (voordeelstoerekening). Second, where a claimant has contributed to the damage, the obligation to repair the damage is reduced by apportioning the damage between the claimant and the defendant, in proportion to the degree in which the circumstances that can be attributed to each of them have contributed to the damage (eigen schuld). Third, judges may mitigate the legal obligation to compensation if full compensation would lead to intolerable results (matiging). See Hartkamp and Sieburgh (2013), para. 98.

152 Where the NIC court imposes a compensation order, the Dutch state now guarantees an advanced payment with a maximum of $€ 5000$. See Advanced Payment Compensation Order Implementation Decree (24 July 2010).
} 
Other challenges remain, too. For instance, the NIC court may need support from a special organ for administrative tasks. Similar to the model of the Trust Fund and the Registry at the ICC, an administrative body could review whether all claims are filed according to procedure, investigate whether victims would appreciate the award of an apology, and perhaps design appropriate standardised awards.

However, for now, it suffices to state that these reparatory standards would strike the right balance between individualised justice and a speedy trial. Their adoption would be a first step in giving the NIC court the opportunity to declare a large number of claims related to international crimes admissible, thereby using its unique position to acknowledge victimhood.

Acknowledgements The authors are grateful to Dr. Brianne McGonigle Leyh and Dr. Diana ContrerasGarduño for their guidance and commentary. All mistakes remain with the authors.

Open Access This article is distributed under the terms of the Creative Commons Attribution 4.0 International License (http://creativecommons.org/licenses/by/4.0/), which permits unrestricted use, distribution, and reproduction in any medium, provided you give appropriate credit to the original author(s) and the source, provide a link to the Creative Commons license, and indicate if changes were made.

\section{References}

Akkermans AJ (2008) Slachtoffers en aansprakelijkheid. Een onderzoek naar behoeften, verwachtingen en ervaringen van slachtoffers met betrekking tot het civiele aansprakelijkheidsrecht, vol II: Affectieschade. WODC, Amsterdam/The Hague

Bitti G, Rivas GG (2006) The reparations provisions for victims under the Rome Statute of the International Criminal Court. In: International Court of Arbitration (ed) Redressing injustice through mass claims processes: innovative responses to unique challenges, 1st edn. OUP, Oxford, pp 299-322

Brienen MEI, Hoegen EH (2000) Victims of crime in 22 European criminal justice systems. WLP, Nijmegen

Calliess G (ed) (2011) Rome regulations. Commentary on the European rules of the conflict of laws. Kluwer Law International, Alphen aan den Rijn

Candido J (2012) Civiel bewijsrecht toepasselijk op vordering benadeelde partij? Gemotiveerde betwisting van een blote stelling. NJB 14:938-940

Candido J et al (2013) Slachtoffer en de rechtspraak, handleiding voor de strafrechtspraktijk. De Rechtspraak. https://www.rechtspraak.nl/SiteCollectionDocuments/Slachtoffer-en-de-Rechtspraak. pdf. Accessed 5 January 2017

Candido J, Lindenbergh SD (2014) Strafrechter en smartengeld. NTBR 5:173-179

Caron DD (2014) International claims and compensation bodies. In: Romano CPR, Alter KJ, Shany Y (eds) The Oxford handbook of international adjudication, 1st edn. OUP, Oxford, pp 278-294

Claassens JCAM (2007) Het slachtoffer in het strafproces. Strafblad 2:79-112

Contreras-Garduño D, Fraser J (2014) The identification of victims before the Inter-American Court of Human Rights and the International Criminal Court and its impact on participation and reparation: a domino effect? IAEHR 7:174-203. doi:10.2139/ssrn.2545000

Correa C (2011) Reparations for victims of massive crimes, making concrete a message of inclusion. In: Letschert $\mathrm{R}$ et al (eds) Victimological approaches to international crimes: Africa, 1st edn. Intersentia, Cambridge, pp 185-234

Cryer R et al (2010) An introduction to international criminal law and procedure. CUP, Cambridge 
Danieli Y (2011) Massive trauma and the healing role of reparative justice. In: Letschert R et al (eds) Victimological approaches to international crimes: Africa, 1st edn. Intersentia, Cambridge, pp 235-260

Das H (2006) The concept of mass claims and the specificity of mass claims resolution. In: The International Bureau of the Permanent Court of Arbitration (ed) Redressing injustices through mass claims processes, innovative responses to unique challenges, 1st edn. OUP, Oxford, pp 3-12

Dwertmann E (2010) The reparation system of the International Criminal Court: its implementation, possibilities and limitations. Martinus Nijhoff Publishers, Leiden

Foroutan A (2003) Medical experiences of Iraq's chemical warfare. Baqiyatallah University of Medical Sciences, Tehran

Gibson C (1997) Using computers to evaluate claims at the United Nations Compensation Commission. Arbitr Int 12:167-192. doi:10.1093/arbitration/12.2.167

Giesen I (2001) Bewijs en aansprakelijkheid. Een rechtsvergelijkend onderzoek naar de bewijslast, de bewijsvoeringslast, het bewijsrisico en de bewijsrisico-omkering in het aansprakelijkheidsrecht. Boom Juridische uitgevers, The Hague

Giesen I, Kristen F, Kool R (2015) The Dutch crush on compensating crime victims. In: Dyson M (ed) Comparing tort and crime. Learning from across and within legal systems, 1st edn. CUP, Cambridge, pp 316-366

Groenhuijsen MS, Pemberton A (2011) Genocide, crimes against humanity and war crimes. A victimological perspective on international criminal justice. In: Letschert $\mathrm{R}$ et al (eds) Victimological approaches to international crimes: Africa, 1st edn. Intersentia, Cambridge, pp 9-34

Hartkamp AS, Sieburgh CH (2013) Mr. C. Assers Handleiding tot de beoefening van het Nederlands burgerlijk recht. Verbintenissenrecht, vol II: De verbintenis in het algemeen. Kluwer, Deventer

Hartlief T (2015) Waar ligt de toekomst van het personenschaderecht? NJB 40:2791

Heiskanen V (2006) Virtue out of necessity: international mass claims and new uses of information technology. In: The International Bureau of the Permanent Court of Arbitration (ed) Redressing injustices through mass claims processes, innovative responses to unique challenges, 1 st edn. OUP, Oxford, pp 25-40

Holtzmann HM, Kristjánsdóttir E (2007) International mass claim processes. Legal and practical perspectives. OUP, Oxford

Human Rights Centre (2015) The victims' court? A study of 622 victim participants at the International Criminal Court. https://www.law.berkeley.edu/wp-content/uploads/2015/04/The-Victims-CourtNovember-2015.pdf. Accessed 5 January 2017

Jofriet JRG (2009) De Wet Internationale Misdrijven. Kluwer, Deventer

Ka Hon Chu S, De Brouwer A, Römkens R (2011) Survivors of sexual violence in conflict. In: Letschert $\mathrm{R}$ et al (eds) Victimological approaches to international crimes: Africa, 1st edn. Intersentia, Cambridge, pp 527-560

Keulen B (2015) Het slachtoffer, de modernisering van het Wetboek van Strafvordering en de rechter. Strafblad 37:240-252

Kool RSB (2014) (Crime) Victims' compensation: the emergence of convergence. ULR 10:14-26. doi:10.18352/ulr.281

Kool RSB et al (2016) Civiel schadeverhaal via het strafproces. Boom Juridische uitgevers, The Hague

Kristjánsdóttir E (2009) International mass claims processes and the ICC Trust Fund for Victims. In: Ferstman C, Goetz M, Stephens A (eds) Reparations for victims of genocide, war crimes and crimes against humanity: systems in place and systems in the making, 1st edn. Martinus Nijhoff Publishers, Leiden, pp 167-196

Letschert R et al (2011) Victimological approaches applied to international crimes. In: Letschert $\mathrm{R}$ et al (eds) Victimological approaches to international crimes: Africa, 1st edn. Intersentia, Cambridge, pp 621-646

Lindenbergh SD (2008) Monografieën BW, Schadevergoeding: algemeen, vol 1. Kluwer, Deventer

Lindenbergh SD (2014) De letselschadevordering in het strafproces. Dat moet beter kunnen. NJB 38:2696-2702

Loth MA, Stegerhoek L (2016) Achter het stuur in de bus. AV\&S 3:94-103

McCarthy C (2012) Reparations and victim support in the International Criminal Court. CUP, Cambridge

Niebergall H (2009) Overcoming evidentiary weaknesses in reparation claims programmes. In: Ferstman C, Goetz M, Stephens A (eds) Reparations for victims of genocide, war crimes and crimes against humanity: systems in place and systems in the making, 1st edn. Martinus Nijhoff Publishers, Leiden, pp 145-166 
Oosterveen WJG, Frenk N (2015) Commentaar op artikel 6:103 BW. In: Nieuwenhuis JH, Stolker CJJM, Valk WL (eds) Tekst \& Commentaar Burgerlijk Wetboek. Kluwer, Deventer

Pemberton A et al (2015) Coherence in international criminal justice: a victimological perspective. ICLR 15:339-368. doi:10.1163/15718123-01502004

Roht-Arriaza N (2004) Reparations in the aftermath of repression and mass violence. In: Stover E, Weinstein HM (eds) My neighbor, my enemy: justice and community in the aftermath of mass atrocity, 1st edn. CUP, Cambridge, pp 121-140

Ruitenbeek-Bart FM, Schijns AJJG (2014) De schadeclaim van het slachtoffer van strafbare feiten; bruggenbouwer tussen twee rechtsgebieden? TVP 2:38-47

Ruvebana E (2011) Victims of the genocide against the Tutsi in Rwanda. In: Letschert R et al (eds) Victimological approaches to international crimes: Africa, 1st edn. Intersentia, Cambridge, pp 89-116

Saris A, Lofts K (2009) Reparation programmes: a gendered perspective. In: Ferstman C, Goetz M, Stephens A (eds) Reparations for victims of genocide, war crimes and crimes against humanity: systems in place and systems in the making, 1st edn. Martinus Nijhoff Publishers, Leiden, pp 79-102

Schijns AJJG (2015) De letselschadevordering van het slachtoffer in het strafproces: een zwakte in de strafrechtelijke slachtofferbescherming. Enkele oplossingsrichtingen voor een verbetering van het schadeverhaal na een misdrijf. TPWS 8:33-40

Schotsmans M (2005) Victims' expectations, needs and perspectives after gross and systematic human rights violations. In: De Feyter $\mathrm{K}$ et al (eds) Out of the ashes, reparation for victims of gross and systematic human rights violations, 1st edn. Intersentia, Antwerpen/Oxford, pp 105-134

Shelton DL (2015) Remedies in international human rights law. OUP, Oxford

Smith N (2014) Justice through apologies. Remorse, reform and punishment. CUP, Cambridge

Stahn C (2015) Reparative justice after the Lubanga Appeal judgment, new prospects for expressivism and participatory justice or 'juridified victimhood' by other means. JICJ 13:801-813. doi:10.1093/ jicj/mqv038

Taylor LA (2009) The United Nations Compensation Commission. In: Ferstman C, Goetz M, Stephens A (eds) Reparations for victims of genocide, war crimes and crimes against humanity: systems in place and systems in the making, 1st edn. Martinus Nijhoff Publishers, Leiden, pp 197-216

Van Boom WH (2007) Effectuerend handhaven in het privaatrecht. NJB 16:982-991

Van Dijck G (2015) Emotionele belangen en het aansprakelijkheidsrecht. NJB 36:2530-2536

Van Dongen JDM, Hebly MR, Lindenbergh SD (2014) Schadeverhaal na misdrijven: ervaringen van slachtoffers. TvVP 1:1-7. doi:10.5553/TVP/138820662014017001001

War Crimes Research Office (2013) Obtaining victim status for purposes of participating in proceedings at the International Criminal Court. https://www.wcl.american.edu/warcrimes/icc/documents/ Report18final.pdf. Accessed 5 January 2017

Wühler N (2003) The different contexts in which international arbitration is being used. International claims tribunals and commissions. JWI 4:379-397

Zegveld L (2009) Compensation for the victims of chemical warfare in Iraq and Iran. In: Ferstman C, Goetz M, Stephens A (eds) Reparations for victims of genocide, war crimes and crimes against humanity: systems in place and systems in the making, 1st edn. Martinus Nijhoff Publishers, Leiden, pp 369-384

Zegveld L (2012) Slachtoffers van internationale misdrijven in het strafproces. NJB 28:1936-1941 